\title{
Frasformade instruktioner med uppföljningar under personlig träning
}

\author{
Av MARTINA HUHTAMÄKI, INGA-LILL GRAHN, JAN \\ LINDSTRÖM, JENNY NILSSON, CATRIN NORRBY \& \\ CAMILLA WIDE
}

\begin{abstract}
Huhtamäki, Martina, martina.huhtamaki@helsinki.fi, Post Doctoral Fellow, Department of Finnish, Finno-Ugrian and Scandinavian Studies, University of Helsinki; Inga-Lill Grahn, ingalill.grahn@svenska.gu.se, Senior Lecturer, Department of Swedish Language, University of Gothenburg; Jan Lindström, jan.k.lindstrom@helsinki.fi, Professor, Department of Finnish, Finno-Ugrian and Scandinavian Studies, University of Helsinki; Jenny Nilsson, jenny.nilsson@sprakochfolkminnen.se, Associate Professor, The Institute for Language and Folklore, Gothenburg; Catrin Norrby, catrin.norrby@su.se, Professor, Department of Swedish Language and Multilingualism, Stockholm University; Camilla Wide, camilla.wide@utu.fi, Professor, Department of Scandinavian Languages, University of Turku: "Phrasal instructions with follow-ups during personal training". Språk och stil NF 29, 2019, pp. 9-40.
\end{abstract}

Personal training is a new form of institutional interaction that has not been extensively studied as regards language. Still, alongside embodied interaction, language is central in this activity. In this paper, phrasal utterances are studied as a resource for instructing in personal training. The data consist of $7 \mathrm{~h} 23 \mathrm{~min}$ of video recordings of training sessions with Swedish-speaking participants from Finland and Sweden, which are supplemented with field notes. The theoretical-methodological framework includes interactional linguistics, ethnography of communication, and variational pragmatics. Results show that participants use all semiotic information at hand when they produce and understand phrasal instructions during personal training. This process involves the overall activity, the participants' institutional roles as trainer and client, their body positions and movements, and trajectories of earlier interaction and embodied elements of the instructions themselves. Phrasal instructions are short; thus, they are focused and easily integrated into the ongoing physical activity. Certain differences are observed between the data from Finland and from Sweden, e.g., Finnish data have more phrasal instructions, whereas the Swedish data have more third-turn follow-ups, which may indicate cultural differences in this domain. The article concludes that phrasal utterances are not only useful as instructions in personal training but also well-suited for the activity type.

Keywords: phrasal utterances, instructions, personal training, interactional linguistics, ethnography of communication, variational pragmatics, Finland Swedish, Sweden Swedish. 
Den grammatiska formen hos ett yttrande hjälper oss ibland att förstå vilken språkhandling en talare avser att uttrycka. Exempelvis kopplas imperativa satser ihop med funktionen direktiv (SAG 1999, 1 s. 41-42, 2, s. 549, 4 s. 705 ff., Lindström m.fl. 2017). Det förekommer samtidigt att flera olika satstyper kan utföra samma språkhandling. En fråga som Vill du stänga fönstret? kan fungera som uppmaning, och en deklarativ sats som Du kommer hit sedan? kan fungera som fråga. Talare anses kunna använda bland annat prosodiska drag för att förtydliga funktionen hos yttranden som inte har den typiska syntaxen för språkhandlingen, exempelvis kan deklarativa frågor och uppmaningar ha stigande intonation (se Gårding 1998 s. 121-122, SAG 1999, 4 s. 677). Studier av frågor med deklarativ syntax i finlandssvensk interaktion har ändå visat att dessa frågor inte har stigande intonation i någon större utsträckning än frågor med interrogativ syntax (t.ex. Huhtamäki 2014).

Det finns även yttranden där den grammatiska formen ger ytterst litet information om vilken typ av språkhandling som avses. Detta gäller fraser som å axlarna, två till och explosivt upp, vilka alla saknar finit verb och subjekt som skulle ge oss mer information om vad någon ska göra med vems axlar, vad som ska ges eller tas två till av, och vem som ska röra vad uppåt på ett explosivt sätt. Tagna ur sitt sammanhang skulle vi knappast förstå att de nämnda yttrandena är instruktioner. Om vi däremot vet att yttrandena uttalas av en personlig tränare under ett träningspass kan vi få en aning om deras innebörd. Ifall vi dessutom vet vad den aktuella övningen går ut på förstår vi ännu mer. Om vi därtill håller på att utföra övningen och är den person som uppmaningen riktas till skulle vi i de flesta fall förstå uppmaningens exakta betydelse. I fråga om dessa yttranden är det alltså kontexten som skapar betydelsen tillsammans med den lingvistiska formen.

I exempel 1 nedan ser vi ett utdrag från en träningssession med en personlig tränare (PT) och en motionär (MO). I utdraget fungerar nominalfrasen hälen (r. 16), adverbfrasen å ut (r. 19) och imperationen stopp (r. 23) som instruktioner, liksom imperativsatsen å sen sträck (r. 25). I övningen ligger motionären på rygg, medan tränaren sitter bredvid henne. Övningen går ut på att motionären ska dra benet mot sig, fälla ut knäet och sedan sträcka ut benet, hela tiden med foten i golvet. Tränaren har introducerat övningen genom att först visa den själv, sedan förklara den med ord och därefter genom att styra motionären med sina händer. Under största delen av övningen tittar tränaren på motionärens ben, medan motionären ser upp i taket. För tolkning av symbolerna, se Transkriptionsnyckel i slutet av artikeln. 


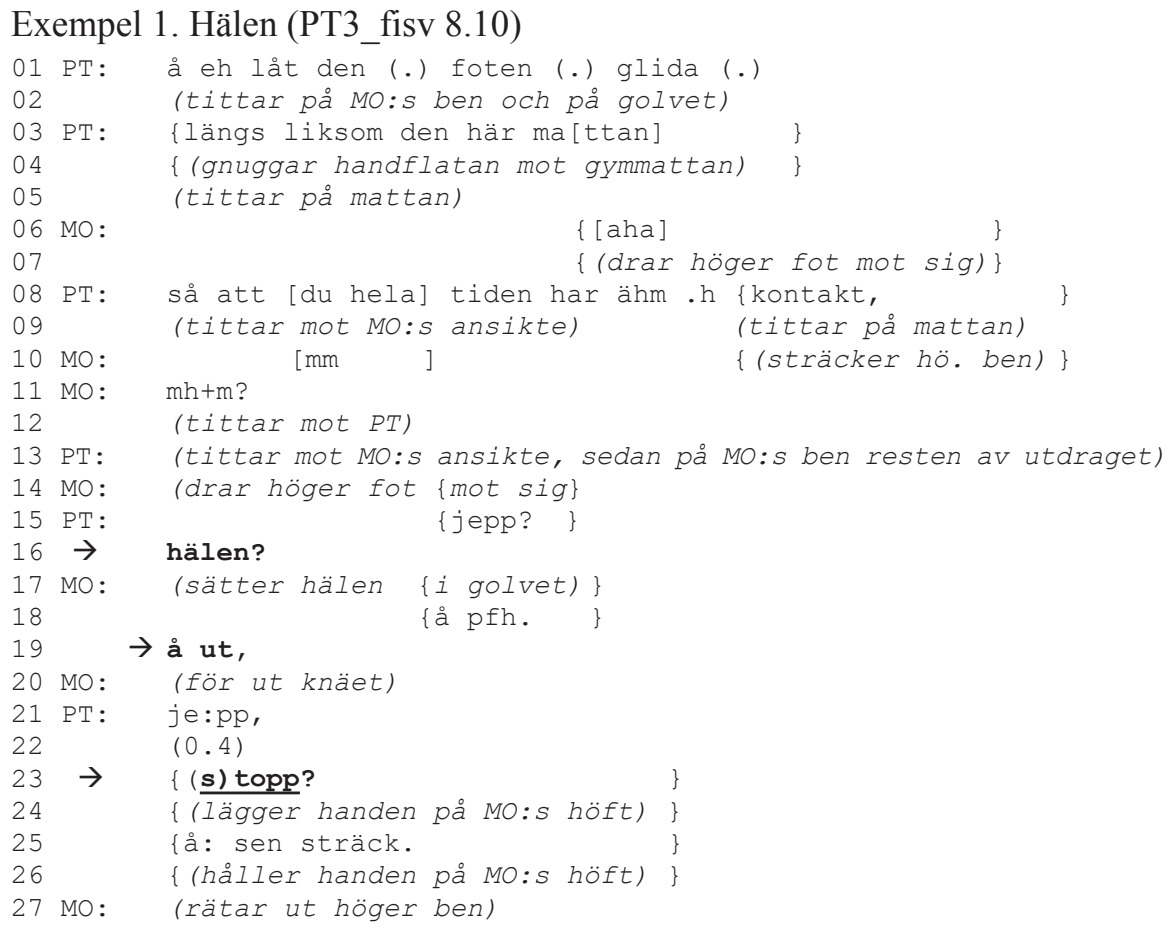

I början av utdraget påpekar tränaren att motionären ska ha sin fot i golvet (r. $1,3,8)$, och motionären visar med responspartiklar att hon förstått (r. 6, 10). Hon prövar också att dra upp och sträcka benet en gång medan tränaren förkla$\operatorname{rar}($ r. 7, 10). Därefter drar motionären benet mot sig igen (r. 14), vilket tränaren bekräftar med uppföljningen jepp (r. 15). Efter detta påminner tränaren om att hälen ska vara i golvet genom att säga hälen (r. 16). Lite senare säger tränaren å ut (r. 19), vilket motionären reagerar på genom att föra knäet ut från kroppen (r. 20). Tränaren bekräftar även denna rörelse med jepp (r. 21). Därefter säger tränaren stopp, samtidigt som hon lägger handen på motionärens höft (r. 23, 24). Påföljande instruktion utgörs av en imperativsats, å sen sträck, varefter motionären rätar ut höger ben (r. 25, 27). Vi ser att motionären tolkar tränarens yttranden som instruktioner eftersom hon följer dem, och tränaren godkänner hennes fysiska prestationer som adekvata i sammanhanget genom att producera uppföljningar och gå vidare i övningen.

Syftet med denna studie är att undersöka vilken typ av resurs frasformade yttranden utgör i instruerande aktiviteter: hur frasformade yttranden används och förstås som instruktioner samt hur de följs upp under personlig träning. 
Tyngdpunkten i vår undersökning ligger på sekventiella analyser av interaktionen, som vi kompletterat med etnografiska studier av den institutionella kontexten. Eftersom vårt material innehåller såväl finlandssvenska som sverigesvenska träningssessioner har vi också ett kontrastivt perspektiv på användning av frasformade instruktioner, och studerar skillnader och likheter varieteterna emellan.

I teori och forskningsbakgrund nedan diskuterar vi definitionen av frasformade yttranden med instruerande funktion samt behandlar relevant forskning om språklig utformning av instruktioner och liknande yttranden. Sedan beskriver vi material och metoder. Därefter redogör vi för resultaten i undersökningen och slutligen sammanfattar och diskuterar vi resultaten.

\section{Teori och forskningsbakgrund}

Den teoretiska och metodologiska referensramen för undersökningen utgörs av en kombination av interaktionell lingvistik, variationspragmatik och kommunikationsetnografi. Interaktionell lingvistik är en forskningsinriktning där språkliga drag studeras med samtalsanalytisk metodik samtidigt som de förankras i en grammatisk analys (Couper-Kuhlen \& Selting 2001, 2018). Samtalsanalys är en induktiv metod med fokus på språkliga, sociala handlingar och deras sekventiella organisation i naturligt förekommande interaktion (Sidnell 2013). Inom variationspragmatiken studeras variation i kommunikativa mönster hos olika varieteter av samma språk (Schneider \& Barron 2008). Exempelvis kan man studera geografisk variation i hur folk hälsar, tackar eller ber om något (Placencia 2008, Grahn 2017, Nilsson m.fl. 2018). Kommunikationsetnografi innebär i sin tur att man studerar förhållandet mellan kommunikationsmönster och kultur (Saville-Troike 2003). För att förstå den kultur som språket är en del av ingår ofta fältarbete (Blommaert \& Jie 2010).

\subsection{Definition av frasformade yttranden med instruerande funk- tion}

De yttranden vi undersöker är frasformade och har instruerande funktion. Denna typ av yttranden är frekventa i personlig träning och således ett centralt element i verksamheten. Frasformade yttranden är en term som används av 
Lindström (2008 s. 70-71) om yttranden som saknar finit verb, i motsättning till satsformade yttranden, såsom imperativsatser. Frasformade yttranden kan utgöras av nominalfraser, verbfraser, adjektivfraser, interjektionsfraser eller prepositionsfraser. De består antingen av enbart ett huvudord, eller av ett huvudord med bestämningar.

Svenska Akademiens grammatik (SAG 1999, 4 s. 783 ff.) kallar yttranden som saknar predikatsled (finit verb) och subjekt för icke satsformade meningar. Sådana kan utgöras av interjektionsfraser, t.ex. stopp, vokativfraser, t.ex. $d u$, eller huvudsatsekvivalenter, t.ex. Hitåt! (alla exempel från SAG). SAG (1999, 4 s. 814) tar upp även militära kommandon som exempel på huvudsatsekvivalenter, såsom Lediga! Enligt SAG skapas huvudsatsekvivalenternas betydelse med hjälp av talsituationen, kontexten och intonationen, medan den grammatiska strukturen spelar en mindre roll (SAG 1999, 4 s. 810). De yttranden vi undersöker motsvarar främst icke satsformade huvudsatsekvivalenter i SAG:s beskrivning. Vi använder dock termen frasformande yttranden i stället för icke satsformade meningar, eftersom den senare antyder en skriftspråklig slagsida; i talspråket finns inte samma förväntan på satsform hos yttranden som i skriftspråket. Dessutom slipper vi definiera en företeelse genom vad den inte är.

Vi har inte undersökt samtliga frasformade yttranden i materialet, utan valt ut dem som har en instruerande funktion. Med instruerande funktion avser vi yttranden som relevantgör en fysisk handling och som också följs av en sådan (se nedan). Funktionen hos yttrandena kunde även beskrivas som uppmaning, direktiv eller begäran om en handling, men vi skiljer inte mellan dessa funktioner, eftersom det inte är relevant för vår undersökning att utreda en sådan distinktion. Det viktiga är alltså att de frasformade yttrandena skapar förväntningar på en fysisk respons hos mottagaren.

\subsection{Forskning om instruktioner och uppmaningar i olika kontexter}

I föreliggande artikel undersöker vi alltså en språkhandling där någon uppmanar någon annan att utföra en fysisk handling och personen utför denna handling. Tidigare forskning har visat att den grammatiska utformningen av sådana yttranden hänger samman med de rättigheter och skyldigheter talaren respektive mottagaren har. Curl \& Drew (2008) fann att talare använde former som Can you i vardagliga samtal då mottagaren har lätt att uppfylla deras önskemål, medan de började sin begäran med I wonder if när de i patientroll begärde något av en läkare. Couper-Kuhlen (2014) har visat hur engelskspråkiga talare väljer 
mellan olika språkliga former för att framföra en begäran beroende på vem som drar nytta av handlingen och vem som förväntas utföra den. Sorjonen \& Raevaara (2014) fann att på finska används nominalfraser ofta när en kund begär att få köpa cigaretter i en kiosk. Den korta formen hänger ihop med den fysiska närheten till varan samt den rutinartade och snabba transaktionen. Enligt Stevanovic \& Peräkylä (2012) behöver talare som har stor deontisk auktoritet, dvs. rätt att bestämma om kommande handlingar, inte förklara eller motivera sina direktiv för att få andra att göra som de vill. I den aktivitet vi undersöker har tränaren rättighet att ge instruktioner och motionären förväntas följa dem. Det är motionären som drar nytta av att följa instruktionerna, t.ex. genom att komma i bättre form. Men det är också bra att motionären förstår vad en viss instruktion syftar till $i$ träningen, vilket kommer fram $i$ att vissa mer utbyggda instruktioner följs upp av tränarens motiveringar (Lindström m.fl. u.u.).

Det har utförts många studier av instruktioner, speciellt inom undervisningskontexter. Den personliga tränarens expertroll påminner om den hos läraren i en undervisningskontext. Lärarens yttranden förväntas generera en (verbal) respons hos eleven, liksom tränarens yttranden förväntas generera en (fysisk) respons hos motionären. Denna respons kan sedan utvärderas av läraren/tränaren. I många undervisningskontexter utgår forskarna därför från en så kallad IRU-struktur ( $I=$ initiering, $R=$ respons, $U=$ uppföljning) eller IRE-struktur $(E=$ evaluering) (se t.ex. Sinclair \& Coulthard 1975, Mehan 1979, Macbeth 2003). Enligt IRU-strukturen uppmanas en person göra något, utför sedan en viss handling och utvärderas därefter enligt ett lokalt operativt kriterium (se Lindwall, Lymer \& Greiffenhagen 2015). I vårt material utgörs initieringen av tränarens uppmaning, responsen av en fysisk prestation, och i vissa fall sker en verbal uppföljning av tränaren.

I en svenskspråkig undervisningskontext har Henricson \& Nelson (2017) funnit skillnader i hur handledare ger råd och hur studenter tar emot råden i Finland och Sverige. Vid högskolorna i Finland framförs råden mer direkt, medan det förekommer fler förmildrande uttryck i Sverige. Råden tas emot med mer uppgraderade uppbackningar i Sverige än i Finland.

En specifik undervisningskontext som är relevant för vår studie är körlektioner. Under körlektioner ska mottagaren i vissa fall reagera på en instruktion med en fysisk handling i nuet, liksom i personlig träning. Inom körlektioner har De Stefani \& Gazin (2014) funnit att frasformade yttranden används som s.k. kontrollinstruktioner. De Stefani och Gazin, som undersökt italiensk interaktion i Schweiz, påpekar att den sekventiella strukturen hos instruktioner under 
körlektioner är mer komplicerad än IRU-strukturen låter förstå. Mer övergripande instruktioner (navigeringsinstruktioner) följs av sekvenser med instruktioner som berör kontroll av fordonet och trafiken (kontrollinstruktioner). Kontrollinstruktioner saknar ofta finit verb och får en fysisk respons, medan navigeringsinstruktionerna utgörs av fullständiga satser och får en verbal respons.

Deppermann (2018) studerade den syntaktiska utformningen av instruktioner under körlektioner på tyska. Även han fann en uppdelning mellan den syntaktiska formen hos instruktioner och de kontexter de används i. Medan deklarativer används som navigeringsinstruktioner används imperativer för att korrigera en pågående handling eller insistera på en handling som borde ha utförts. Jämfört med deklarativerna är imperativerna korta och kan vid behov produceras snabbt. De frasformade instruktionerna i vårt material påminner i detta avseende om imperativerna.

När det gäller svenskspråkig interaktion har forskare påvisat en arbetsfördelning mellan yttranden med olika grammatisk utformning i en vårdkontext. Även vårdkontexter påminner om personlig träning, eftersom det är fråga om en expert som ska hjälpa en person med det fysiska välbefinnandet. Lindström m.fl. (2017) har i en undersökning av imperativer under läkarbesök på svenska i Finland och Sverige visat att läkaren i början och slutet av besöket använder modifierande element tillsammans med imperativer (adverb/partiklar: berätta lite eller artighetsfraser: varsego ta på skjortan), medan läkaren under den fysiska undersökningen använder raka imperativer. En förklaring är att imperativerna i undersökningen är starkare knutna till den fysiska aktiviteten, ofta inbäddade i serier av direktiva handlingar. I vår undersökning kan vi förvänta oss att de frasformade instruktionerna hör mycket nära ihop med den fysiska aktiviteten.

Förutom att använda verbala instruktioner är det även möjligt att använda sin kropp för att ge instruktioner och uppmaningar. Detta är speciellt relevant när den fysiska aktiviteten är i förgrunden, såsom i personlig träning. Keevallik (2013) har visat hur danslärare använder instruktioner som består av en verbal syntaktisk del (dvs. en sats) som projicerar en fortsättning, och en fysisk del som fullbordar projektionen. Exempelvis säger dansläraren vid ett tillfälle: för om killarna gör och utför en kroppslig demonstration, och fortsätter: så kommer ju tjejerna att göra och utför en ny demonstration (s. 8). Cekaite (2010) beskriver i sin tur hur föräldrar i svenska medelklassfamiljer styr sina barn genom verbala, kroppsliga och rumsliga praktiker. Föräldrar kan ta tag i sina barn, svänga deras kroppar och fösa dem dit de borde röra sig för att till exempel borsta tänderna. Föremålen i hemmet begränsar vart barnet kan röra sig. De 
återkommande aktiviteterna och den gemensamma förståelsen av situationen bidrar till att de kroppsliga direktiven fungerar. Nishizaka (2016) pekar också på hur yttrandets syntaktiska form spelar en roll för hur deltagare koordinerar verbala och fysiska handlingar under massage.

Lundin (2018) har studerat språkbruket under idrottsträningar för barn med hjälp av funktionell grammatik. Hon fann fem typer av yttranden med uppmanande funktion: enkelt presens, presens med det modala hjälpverbet $s k a$, imperativ, frågesats eller »icke-verbburen exklamativ» (s. 158). Icke-verbburna exklamativer är detsamma som vi kallar frasformade instruktioner. Hon ger exemplet Upp med knäna! men säger inte något mera om dessa uppmaningar. Tidigare studier att nämna i angränsande områden är t.ex. Martin \& Sahlström 2010 som undersöker lärande i fysioterapeutisk behandling.

Vad vi vet finns det inte några tidigare undersökningar av svensk interaktion om just frasformade yttranden som fungerar som instruktioner, förutom en pilotstudie av Grahn \& Huhtamäki (2019). Vår undersökning bidrar således till kunskapen om hur frasformade yttranden används och förstås som instruktioner i den institutionella verksamhet som personlig träning utgör. Vi ser vår studie både som ett bidrag till hur språkliga resurser används interaktionellt och till hur språket är en integrerad del av en viss verksamhet, här den hittills tämligen outforskade friskvårdsdomänen. Därtill bidrar vår jämförelse av frasformade instruktioner i finlandssvenska och sverigesvenska till ökad kunskap om svenskan som pluricentriskt språk.

\section{Material och metoder}

Undersökningen utgör en delstudie inom forskningsprogrammet Interaktion och variation i pluricentriska språ $k^{1}$ vars syfte är att jämföra kommunikationsmönster i svenskan i Finland och svenskan i Sverige inom olika domäner (jfr Schneider \& Barron 2008). Således utgörs hälften av vårt material av videoinspelningar från Finland och andra hälften av inspelningar från Sverige med personliga tränare och motionärer. Som kompletterande material används fältan-

\footnotetext{
${ }^{1}$ Programmet Interaktion och variation i pluricentriska språk är finansierat av Riksbankens Jubileumsfond (M12-0137:1) och pågår 2013-2020. Inom programmet samarbetar forskare från Stockholms, Helsingfors och Åbo universitet samt Institutet för språk och folkminnen i Göteborg. Se Norrby m.fl. 2012, 2014 och http://www.su.se/svefler/ivip. Vi tackar Riksbankens Jubileumsfond för stöd till forskningsprogrammet och Klara Skogmyr Marian för hjälp med analysen av uppföljningarna.
} 
teckningar vi tagit vid besöken på inspelningsplatserna, som hjälper oss att förstå aktiviteten personlig träning och den kontext där den äger rum (jfr Saville-Troike 2003, Blommaert \& Jie 2010; se avsn. 3 nedan).

Inspelningarna utfördes under träningspass som hade ägt rum oberoende av vår undersökning. Vi kontaktade de personliga tränarna och de frågade i sin tur motionärerna. Samtliga tränare och motionärer har tränat tillsammans tidigare och vissa känner varandra väl. Både tränarna och motionärerna var medvetna om att vi undersöker språk och interaktion och hade gått med på att vi spelade in dem. Alla personnamn och annan information som skulle göra det möjligt att identifiera personerna har anonymiserats i samtalsutdragen och på bilderna. Projektet har godkänts av etiknämnder i respektive länder.

Inspelningarna utgör sammanlagt 7 timmar och 23 minuter, relativt jämnt fördelat mellan Finland och Sverige (se tabell 1). I materialet ingår fyra träningspass med tre olika tränare från Finland och tre träningspass med två olika tränare från Sverige. Antalet olika motionärer är fyra i både Finland och Sverige. Vanligen deltar en tränare och en motionär i träningspassen, men i Sverige utgörs ett pass av gruppträning med en tränare och tre motionärer. I rubriken till transkriptionerna betecknas inspelningarna med nummer och landskod, exempelvis syftar PT1_fisv på den första inspelningen från Finland.

Tabell 1. Materialöversikt.

\begin{tabular}{lccccc}
\hline & Inspelningslängd & $\begin{array}{c}\text { Ant. } \\
\text { träningspass }\end{array}$ & Ant. tränare & $\begin{array}{c}\text { Ant. } \\
\text { motionärer }\end{array}$ & $\begin{array}{c}\text { Ant. } \\
\text { frasformade instr. }\end{array}$ \\
\hline Finland & 3 tim. $47 \mathrm{~min}$ & 4 & 3 & 4 & $406^{2}$ \\
Sverige & $3 \mathrm{tim} .36 \mathrm{~min}$ & 3 & 2 & 4 & 211 \\
Totalt & 7 tim. 23 min & 7 & 5 & 8 & 617 \\
\hline
\end{tabular}

I inspelningarna har vi excerperat 617 sekvenser där ett frasformat yttrande från en deltagare direkt följs av en fysisk handling från en annan. ${ }^{3}$ Den utförda fysiska handlingen visar hur det aktuella yttrandet förstås som en instruktion, eller kanske uppmaning, i situationen. I vissa sekvenser följer också en avslutande uppföljning av motionärens prestation från tränaren, vilka också ges plats i analysen. Urvalskriterierna tar därmed hänsyn till både form (se punkt 1 och 2), sekventiell placering (se punkt 2 och 3 ) och funktion (se punkt 2 och 3 ):

\footnotetext{
${ }^{2}$ I Grahn \& Huhtamäki (2019) anges att det finns 399 frasformade instruktioner i det finländska delmaterialet, men en fördjupad analys ger denna summa.

${ }^{3} \mathrm{Vi}$ har inte utfört någon jämförelse mellan frasformade och andra typer av instruktioner i vårt material, men de frasformade är mycket frekventa och varvas med deklarativa och imperativa satser.
} 
1) Yttrandena saknar finit verb, dvs. de utgörs av frasformade yttranden (se Lindström 2008 s. 70-71, jfr SAG 1999, 4 s. 783; se avsnitt 1.1 ovan).

2) Yttrandena utgör självständiga syntaktiska, prosodiska och pragmatiska enheter i sin kontext (se Sacks m.fl. 1974 s. 720-721, Ford \& Thomson 1996, Bockgård 2007).

3) Yttrandena fälls under pågående fysisk aktivitet och följs direkt av en fysisk handling.

Vi har enbart excerperat yttranden som inte är syntaktiskt beroende av en språklig konstruktion i en tidigare tur, dvs. elliptiska yttranden. Detta innebär att vi har uteslutit fraser som parasiterar på ett finit verb i en föregående tur, såsom frasen hela vägen nu som följer på den imperativa satsen kom igen i den föregående turen (ex. 2):

\section{Exempel 2: kom igen / hela vägen $n u$}

Vi behandlar motionärernas fysiska respons som en bekräftelse på att de förstått tränarens instruktion (se Sacks \& Schegloff 1973, Mondada 2011). Ibland är den fysiska responsen tydlig, såsom när motionären lyfter benen, men ibland är det fråga om utifrån sett mer subtila förändringar, såsom att spänna magmusklerna eller ändra kroppshållningen en smula (jfr Martin 2004 om modifierade rörelser som respons). Även om motionärens fysiska aktivitet inte alltid utgör en respons på en instruktion, utan i stället är en fortsättning av övningen, hänger de två så nära ihop att det i vissa fall är omöjligt att skilja dem åt. Exempel på sådana fall är räkning som fungerar som instruktion. I en del fall följs den fysiska responsen av tränarens godkännande uppföljning, som ytterligare bekräftar att motionären har tolkat instruktionen rätt.

I enlighet med samtalsanalytiska principer utför vi sekventiella analyser av de utdrag ur inspelningarna där de frasformade instruktionerna ingår (se Sidnell 2013). I dessa beaktar vi vilken verbal information som föregår instruktionen och hur den fysiska prestationen följs upp. Vi studerar den lexikala, syntaktiska och prosodiska utformningen av den frasformade instruktionen samt kroppslig (visuell och taktil) information som kombineras med den. För presentationen av exemplen har vi transkriberat utdrag ur inspelningarna enligt principerna för transkription av samtalsmaterial (Lindström 2008, Hepburn \& Bolden 2013). I de utvalda sekvenserna utförs så gott som hela tiden fysiska övningar, och för att transkriptionerna ska bli läsbara har vi begränsat återgivningen till metakommentarer av för analysen relevanta multimodala drag. 
Överlappande tal betecknas med [ ], medan fysisk aktivitet som överlappar tal betecknas med \{ \}. Fullständig transkriptionsnyckel återfinns sist i artikeln. Vi bifogar även bilder för att hjälpa läsaren att få en uppfattning om deltagarnas kroppspositioner under övningen.

\section{Personlig träning som institutionell verksamhet}

Den verksamhet som vårt material är hämtat från kan beskrivas som institutionell eftersom en av deltagarna, tränaren, utövar sin yrkesroll och det finns ett tydligt mål för verksamheten (se Drew \& Heritage 1992 s. 3-4, Heritage 1997, Linell 2011 s. 109). Den omfattar både fysisk aktivitet och samtal, som deltagarna koordinerar i sin interaktion. Personlig träning är en relativt ny näringsgren som George (2008) klassificerar som servicearbete på expertbasis. Enligt henne kännetecknas branschen av att en standardiserad utbildning för personliga tränare saknas, vilket gör att tränarna måste visa sin expertis extra tydligt $\mathrm{i}$ interaktionen med motionärerna. Våra analyser visar dock att tränaren i de flesta fall har en självklar auktoritet i förhållande till motionären.

Deltagarnas institutionella roller innebär asymmetri gällande kunskap samt rättigheter och skyldigheter (jfr Drew \& Heritage 1992 s. 3-4, Linell 2011 s. 109). Till tränarens roll hör att instruera, undervisa och uppmuntra motionären (se George 2008). Motionären förväntas i sin tur ta emot råd och utföra övningarna (jfr De Stefani \& Gazin 2014, Lundin 2018). I de flesta inspelningarna förekommer även avsnitt där tränaren och motionären småpratar med varandra (jfr George 2008). De personliga tränarna bär ofta t-skjorta med gymmets logo, vilket innebär att de är lätta att identifiera som tränare. Till deltagarramen bidrar i hög grad tränarens och motionärens kroppspositioner och rörelser (jfr t.ex. Goffman 1981, Goodwin 2000). Tränares instruerande roll syns på att de ofta intar en övervakande kroppsposition i förhållande till motionärerna.

Den fysiska miljön är i de allra flesta fall ett gym, det vill säga en halvoffentlig miljö där motionären måste betala för att få träna. ${ }^{4}$ Motionären betalar också för den personliga tränarens tjänster, så det är alltså fråga om en kundrelation. Även i den fysiska miljön förekommer instruktioner och uppmaningar i skriven

\footnotetext{
${ }^{4}$ Ett undantag är en av inspelningarna som skedde i motionärens hem, PT3_fisv.
} 
form av olika storlek och formalitet. Dessa förstärker den institutionella kontexten och deltagarramen, eftersom instruktionerna endast gäller motionären. Det kan vara fråga om instruktioner för hur motionärerna ska handla här och nu, såsom att torka av träningsmaskinen med en trasa efter användning, instruktioner för hur övningarna ska utföras på rätt sätt och tips för hur de kan stretcha samt uppmaningar som också kan appliceras på livet utanför gymmet, exempelvis Believe in yourself, you are stronger than you think!

Föremålen på gymmet styr in verksamheten på en viss typ av träning. Motionärens kropp och rörelser avgränsas av vissa föremål, såsom gymmattor, träningsmaskiner och olika redskap (jfr Cekaite 2010). Motionären kan exempelvis ligga på en gymmatta med benen på en stor boll, vilket möjliggör en begränsad uppsättning rörelser. Träffarna mellan personliga tränare och motionärer är ofta upplagda enligt ett relativt fast program som vanligen inkluderar uppvärmning och övningar (jfr Lundin 2018 s. 155).

De frasformade instruktionerna används alltså under en aktivitet där de institutionella rollerna är tydliga och i en miljö som är utformad för fysisk träning. Det finns således många element både i omgivningen, aktiviteten, deltagarramen och i den kroppsliga och verbala kommunikationen som skapar betydelser för deltagarna (se Goodwin 2000).

\section{Frasformade instruktioner under träningspassen}

I detta avsnitt ger vi först en överblick över semantiskt innehåll och grammatisk form hos de frasformade yttrandena vi undersökt. Därefter presenteras en analys av fyra sekvenser som illustrerar hur yttrandena används och tas emot under träningspassen.

De frasformade instruktionerna används för att finjustera och korrigera motionärens prestation samt för att uppmuntra motionären att göra sitt bästa. De förekommer både under själva övningen och vid inledningen till en övning när motionären ska inta rätt position. Som exempelanalyserna visar varvas de frasformade instruktionerna med instruktioner som har deklarativ eller imperativ syntax. De kombineras ibland med visuella eller taktila instruktioner, och denna typ av instruktioner kan även förekomma utan verbala element.

De frasformade instruktioner vi studerat hänvisar till situerade element $\mathrm{i}$ aktiviteten. Vi har identifierat två huvudsakliga typer av element som före- 
kommer i materialen från både Finland och Sverige. Huvudtyperna utgörs av 1) räkning före en prestation (ex. nu sista) och 2) referens till kropp eller riktning (ex. å sen vaden; å sen ner), eventuellt tillsammans. Den förstnämnda typen hjälper motionären att orientera sig tidsmässigt i övningen och den andra anger vilken kroppsdel de ska röra på och/eller vartåt de ska röra på den.

Grammatiskt sett utgörs de undersökta yttrandena av nominalfraser, verbfraser, adjektivfraser, interjektionsfraser eller prepositionsfraser. Därtill förekommer en frastyp som vi benämner räkneordsfraser. Fraserna består av ett huvudord, med eventuella bestämningar (jfr Lindström 2008 s. 71). Omnämnande av kropp utgörs grammatiskt sett ofta av nominalfraser som anger vilken kroppsdel motionären ska fokusera på, exempelvis hälen (se ex. 1 ovan). Omnämnande av riktning består i stor utsträckning av adverbfraser som anger vartåt motionären ska röra en viss kroppsdel, exempelvis å ut (se ex. 1). Kropp och riktning kan också kombineras i en instruktion, till exempel adverbfrasen upp med bröstet (se ex. 5). Räkneordsfraserna utgörs av räkneord, ibland även med bestämning, såsom två till (se ex. 3). De instruktioner som hänförs till övriga refererar bland annat till sättet på vilket en övning ska utföras, exempelvis adjektivfraserna stark och lugn å fin, eller av nominalfraser som benämner en rörelse eller ett moment i övningen, såsom inandning och å: paus.

\subsection{Frasformad instruktion som utgörs av räkning}

I vårt material finns många exempel på när tränaren använder räkneordsfraser för att leda motionären genom övningen, det vill säga uttalar en siffra som anger vilken repetition i ordningen som motionären just utför eller utfört. Vi har kallat detta fenomen för medräkning, och dessa yttranden utgör inte instruktioner eftersom de uttalas samtidigt med eller strax efter den handling de refererar till. De räkneordsfraser som vi bedömt har en instruerande funktion uttalas istället före den fysiska handling som refereras till och kan därmed anses projicera denna handling. Ofta förekommer både medräkning och instruerande räkning i samma sekvens, vilket visas i exempel 3. Före utdraget har tränaren visat utgångspositionen och berättat vad övningen går ut på: att hålla händerna i golvet, ena benet böjt framför sig och det andra rakt bakåt, och sedan föra det bakre benet mot armbågen tio gånger. Tränaren sitter först på knä bredvid motionärens huvud och ställer sig sedan upp. Under sekvensen iakttar tränaren hela tiden motionären, som tittar i golvet. 


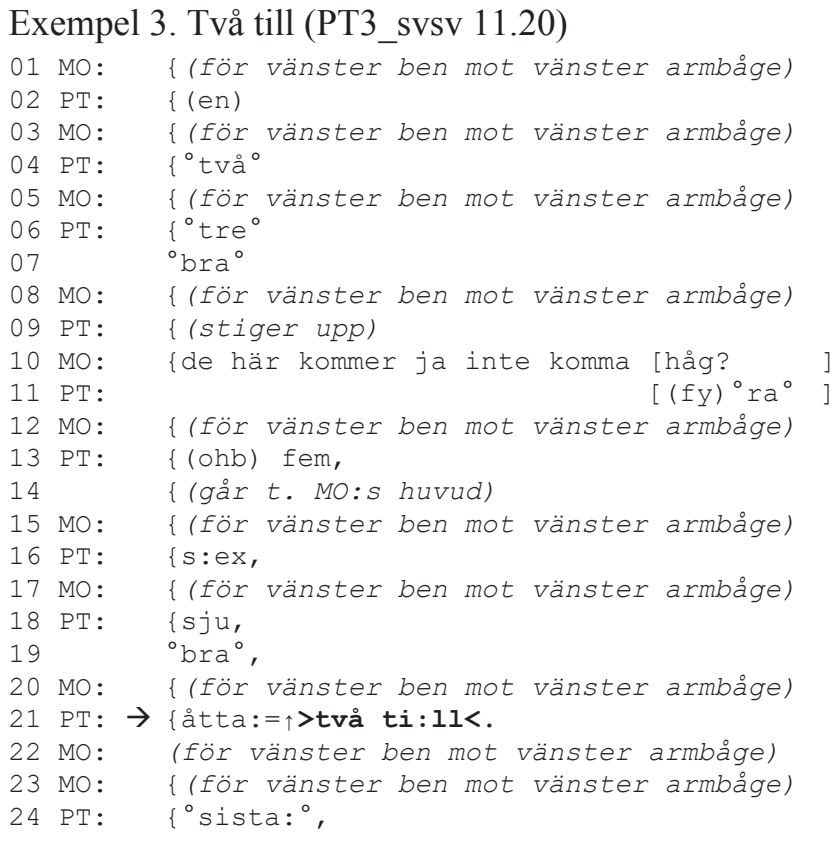

Före utdraget kontrollerar motionären att hon är i rätt position (se bild 1; pilarna betecknar blickriktning) och har förstått övningen på rätt sätt, vilket tränaren bekräftar. Sedan börjar motionären utföra övningen (från r. 1; se bild 2). Tränaren hjälper motionären att räkna de repetitioner hon utför genom att säga en siffra med låg ljudstyrka samtidigt med varje repetition (t.ex. r. 2). Hon gör även ett par positiva evalueringar med låg ljudstyrka (r. 7, 19).

Direkt efter att ha sagt åtta (r. 21) ökar tränaren taltempot och säger två ti:ll. Frasen två till sägs just innan motionären hunnit påbörja nästa repetition och pekar på vad motionären ska göra härnäst, vilket ger frasen en instruerande funktion. Den skiljer sig prosodiskt från de tidigare medräkningarna och uppföljningarna genom en aningen ökad ljudstyrka och tonhöjd. Talhastigheten hos $t v a ̊$ till är snabbare jämfört med åtta, vilket innebär att den inte bryter rytmen hos repetitionerna, utan tränaren hinner säga frasen just innan motionären ska utföra nästa repetition. Motionären utför repetition nummer nio och tio och medan hon utför den sista säger tränaren ett prosodiskt nertonat sista: (r. 24), vilket fungerar som medräkning. Tränaren signalerar genom att gå vidare i programmet att sekvensen genomförts på det sätt som var tänkt. 


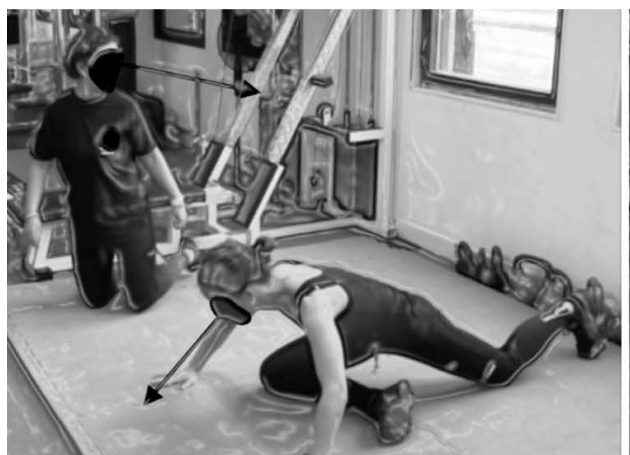

Bild 1. Utgångsposition.

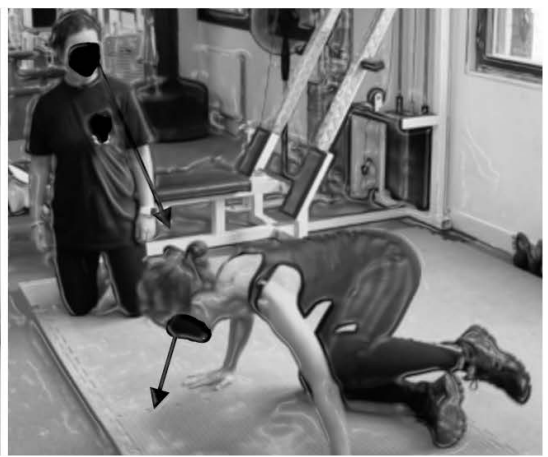

Bild 2. Övningen utförs.

Räkneordfraserna $\mathrm{i}$ vårt material har en uppmuntrande och motiverande funktion, genom att de hjälper motionärerna att hålla reda på var de befinner sig $\mathrm{i}$ övningen och därmed ge dem möjlighet att kanalisera sina krafter därefter. Detta gäller även de räkneordsfraser som uttalas före en repetition, men dessa har samtidigt drag av instruktion eftersom de projicerar en direkt fysisk handling.

\subsection{Frasformade instruktioner som refererar till kroppsdel och/ eller riktning}

I exempel 4 används två frasformade instruktioner som anger både kroppsdel och riktning: opp me benen tibaks (r. 4) och ansikte lite hitåt (r. 7). Båda instruktionerna åtföljs av taktila demonstrationer, dvs. tränaren anger genom beröring vilken kroppsdel motionären ska röra på respektive i vilken riktning. Utdraget är från början av en övning då tränaren ger anvisningar om positionen. Övningen går ut på att ligga på rygg med ett gymblock mellan knäna och benen i nittio graders vinkel och röra benen (se bild 3 ). Motionären blundar under övningen. Hon har nyss avslutat en annan övning som också utfördes på rygg. Tränaren sitter på knä till vänster om henne. Först följer tränaren upp motionärens tidigare prestation, de gick jättefint (r. 1). Uppföljningen utgörs av en evaluering av högre positiv grad, det vill säga, den utvärderar motionärens prestation starkt positivt (jfr avsnitt 4.4 nedan). 


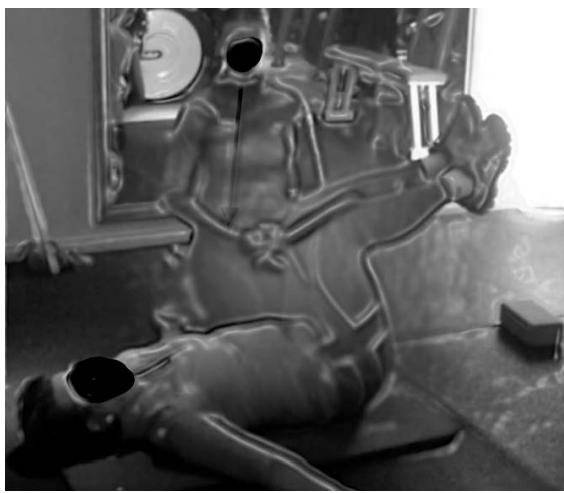

Bild 3. Utgångsposition.

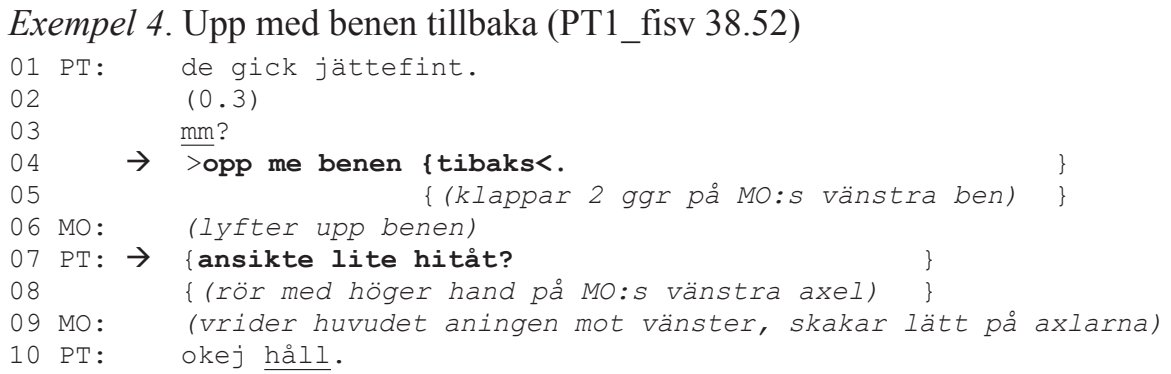

Därefter säger tränaren opp me benen tibaks (r. 4), snabbt och med fallande slutintonation. Adverbet opp anger riktning för rörelsen, prepositionsfrasen me benen tillsammans med beröringen i slutet av instruktionen anger vilken kroppsdel rörelsen gäller och adverbet tibaks 'tillbaka' hänvisar till den föregående övningen (jfr Torpo 1998 om finitlösa direktiv under aerobiclektioner på finska). Motionären lyfter upp benen som respons.

Sedan säger tränaren ansikte lite hitåt (r. 7), och lägger för ett ögonblick höger hand på motionärens vänstra axel. Denna instruktion produceras med stigande slutintonation. Det frasformade yttrandet refererar till en kroppsdel, ansikte $(t)^{5}$, en riktning, hitåt, och en gradering, lite. Genom beröringen anger tränaren vad det deiktiska adverbet hitåt syftar på. Motionären responderar genom att vrida huvudet en aning åt vänster. Därefter bekräftar tränaren motionärens position med okej och ger utan paus en ny instruktion med imperativet håll (r. 10).

${ }^{5}$ Det går inte att avgöra om substantivet ansikte används i bestämd eller obestämd form utifrån hur ordet uttalas, eftersom det saknar slut-t i båda fallen i talad finlandssvenska. 
De verbala instruktionerna är finkoordinerade med beröringar som därmed också blir instruerande. Beröringarna framhäver och preciserar de verbala instruktionerna, men vore inte ensamma tillräckliga för att motionären skulle kunna inta rätt position. Beröringarna är speciellt viktiga i denna sekvens eftersom motionären inte är tillgänglig för synintryck. Genom att tränaren går vidare i programmet efter motionärens fysiska respons (r. 7) signalerar hon att motionären responderat på ett förväntat sätt. Efter motionärens fysiska respons på den andra instruktionen producerar tränaren därtill den bekräftande uppföljningen okej (r. 10), vilket visar att motionärens respons är korrekt. Därefter produceras nästa instruktion utan paus, vilket tyder på att uppföljningen dessutom fungerar som övergångssignal.

Exempel 5 visar en sekvens med fyra frasformade instruktioner som refererar till en kroppsdel och/eller riktning. I detta utdrag används de frasformade instruktionerna för att hjälpa motionären att inta rätt position i början av en övning och stödja honom $i$ att göra rörelserna på ett korrekt sätt. Övningen går ut på att i lätt framåtböjd position lyfta en skivstång från knähöjd upp till höfthöjd. Tränaren står till vänster om motionären under utdraget och övervakar hans rörelser.

Exempel 5. Brett isär med fötterna (PT1_svsv 01.13.00)

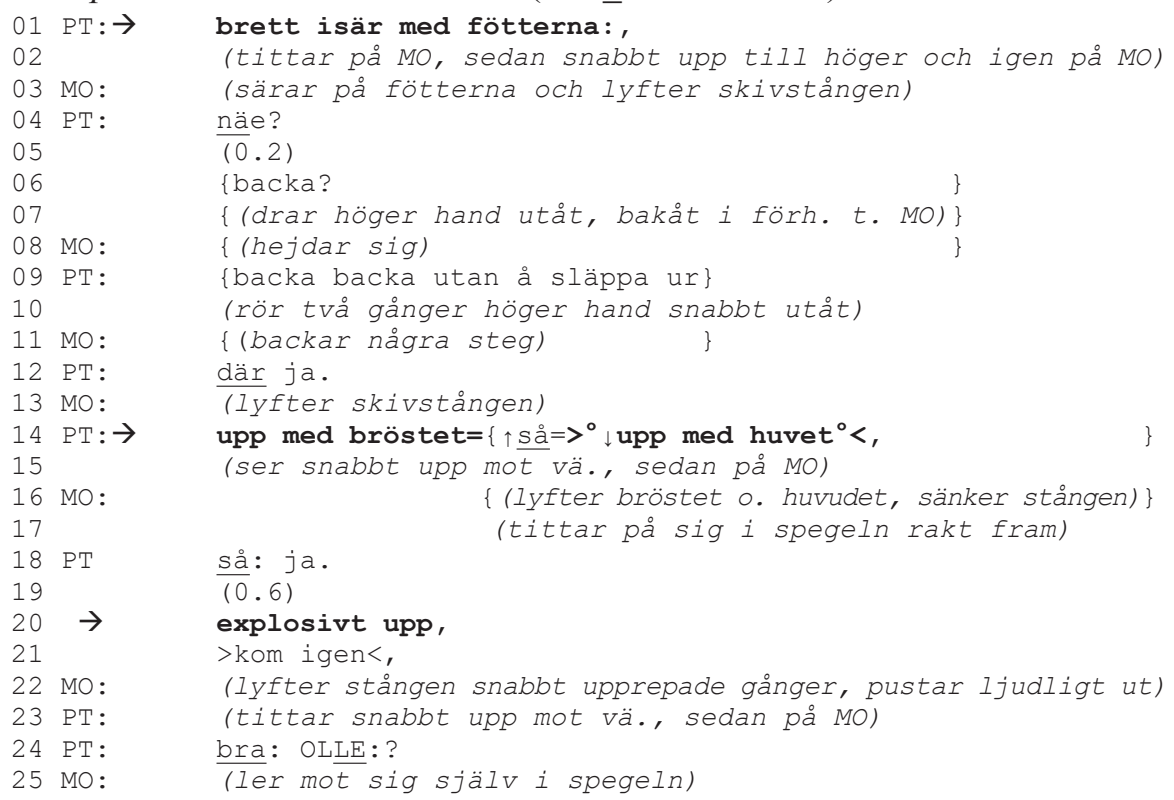


Den första frasformade instruktionen utgörs, liksom de tre andra, av en adverbfras: brett isär med fötterna (r. 1). Tränaren uttalar den sista stavelsen förlängd och med jämn slutton (jfr Karlsson 2010 om platåintonation i listor). Motionären flyttar isär fötterna en aning och påbörjar övningen, men tränaren ger en negerande respons på hans prestation och en ny, korrigerande instruktion i imperativ: näe (0.2) backa backa backa utan å släppa ur samtidigt som han med höger hand gör en gest mot det som är bakåt ur motionärens synvinkel (r. 4-7, 9-10). Upprepningen av backa kan signalera brådska (jfr De Stefani \& Gazin 2014 s. 68), vilket verkar vara fallet här då skivstången är tung och motionärens aktivitet ska korrigeras omedelbart. Motionären hejdar sig i lyftet och backar med skivstången. Efter det producerar tränaren uppföljningen där ja (r. 12).

Motionären börjar lyfta skivstången igen, men tränaren korrigerar återigen hans position med två frasformade instruktioner med ett kort godkännande $s a ̊$ mellan: upp med bröstet så upp med huvet (r. 14). Den senare frasen, upp med huvet uttalas snabbt, med låg ljudstyrka och jämn slutintonation. Motionären responderar genom att lyfta bröstet och huvudet (se bild 4). Därefter sänker han stången till utgångsläget. Tränaren godkänner motionärens position med så ja med stigande-fallande intonation (r. 18), och övergår sedan till att ge en ny frasformad instruktion, explosivt upp (r. 20), följt av ett lexikaliserat uppmuntrande uttryck i imperativ, kom igen (r. 21). Båda instruktionerna har jämn slutintonation och kom igen uttalas mycket snabbt.

Koordineringen av instruktionerna med motionärens rörelse är extra viktig här eftersom skivstångens tyngd gör att han riskerar att skada sig ifall han missförstår dem. Motionären lyfter stången kraftfullt ett antal gånger, varefter tränaren evaluerar hans prestation positivt, bra: OLLE: (r. 24). Denna uppföljning som till sin lexikala utformning är en evaluering av lägre positiv grad (se avsn. 4.4 nedan), får ökad tyngd genom att den uttalas med förlängning, ökad ljudstyrka och stigande slutintonation. Uppföljningen kan alltså beskrivas som prosodiskt uppgraderad jämfört med den föregående instruktionen (se Curl 2002, Ogden 2006), och mer framträdande än de andra uppföljningarna i sekvensen. Under denna sekvens följer tränaren upp den fysiska prestationen efter varje instruktion, så att en IRU/IRE-sekvens bildas (jfr Sinclair \& Coulthard 1975, Mehan 1979, Macbeth 2003; jfr Schegloff 2007 s. 118,124 om sequence-closing thirds). I de flesta fall bekräftar tränaren att motionären uppfattat instruktionen rätt, men i ett fall säger tränaren att motionären gör fel. 
Bild 4. Korrigerad position.

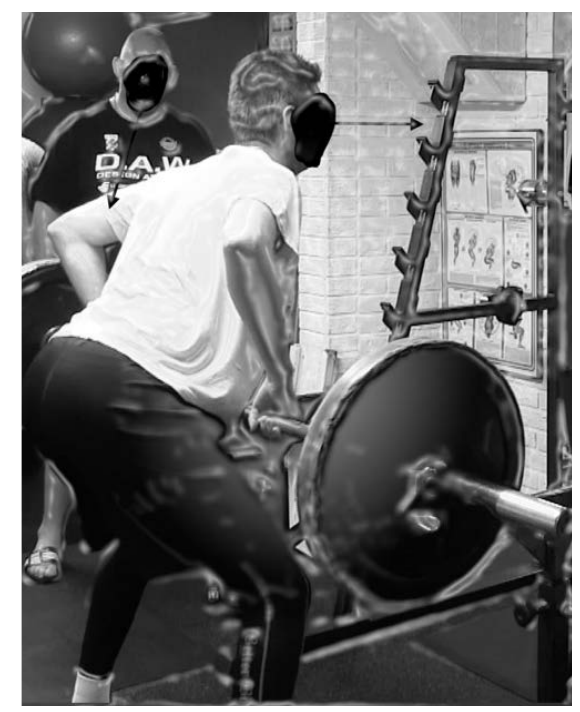

\subsection{Koordineringen av en frasformad instruktion och en fysisk demonstration}

Det är mindre vanligt att tränaren gör en övning samtidigt med motionären, men detta sker i följande exempel där frasen å axlarna (r. 20) kombineras med att tränaren visar övningen. I exemplet skapas motionärens förståelse av den frasformade instruktionen i hög grad genom koordinationen med tränarens fysiska rörelser. Tränaren och motionären står mitt emot varandra och håller i varsin gymnastikpinne med ett brett grepp. Övningen går ut på att föra pinnen ovanför huvudet, andas ut och föra ner den igen. Detta är en ny övning, och tränaren har inte gett några instruktioner före övningen utan instruerar den stegvis. Utdraget är från början av övningen: rad 1-6 utgör slutet av den första repetitionen, rad 11-22 den andra repetitionen. Att röra på axlarna introduceras i slutet av den andra repetitionen.

Exempel 6. Och axlarna (PT2_fisv 17.02)

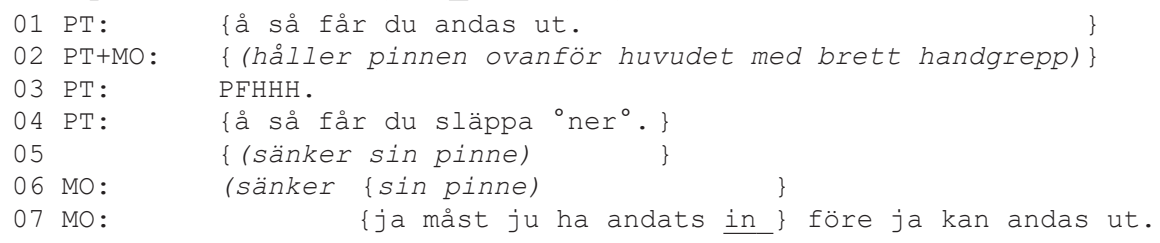




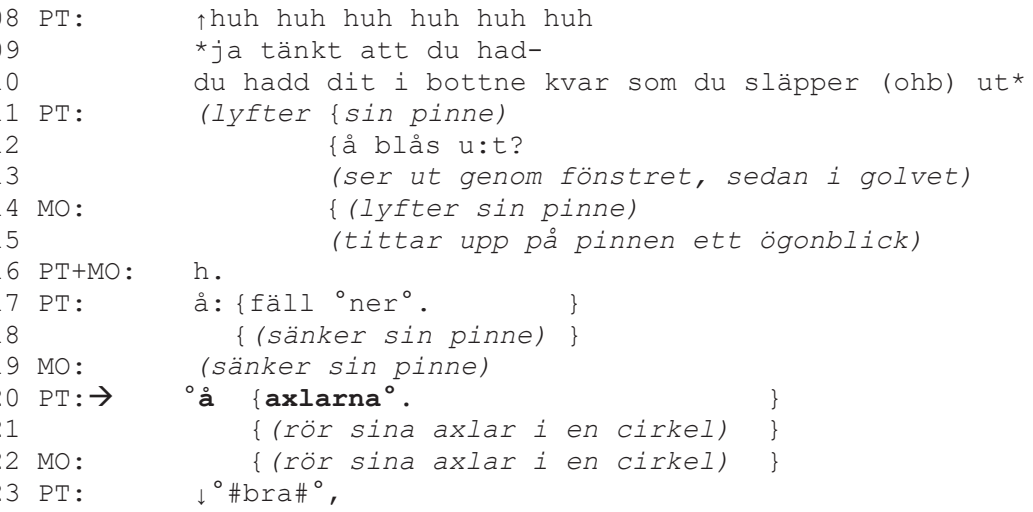

I utdraget ger tränaren en rad instruktioner, både i form av deklarativa satser (r. 1,4), imperativa satser (r. 12, 17) och i form av en fras (r. 20). Samtliga instruktioner inleds med konjunktionen $a$ ' 'och', som här binder ihop element med instruerande funktion och hänvisar till en institutionell agenda (jfr Heritage \& Sorjonen 1994). Motionären svarar enbart fysiskt på instruktionerna, med undantag av rad 7 där hon skämtsamt protesterar mot att tränaren gett bristfälliga instruktioner.

Genom placeringen mitt emot varandra kan tränaren se vad motionären gör och vice versa. De har ögonkontakt nästan hela tiden och i transkriptionen anges bara när de inte har det. Ögonkontakten är en förutsättning för att motionären ska veta hur övningen går till. Tränaren koordinerar sina verbala instruktioner med såväl sina egna som med motionärens rörelser och varje instruktion kommer precis när motionären är redo att följa den. Exempelvis både påbörjar och avslutar tränaren sin fysiska rörelse och verbala instruktion samtidigt på rad 4 och 5 , och påbörjar nästa verbala instruktion på rad 12 när pinnen är nästan uppe. Den fysiska demonstration som äger rum på rad 11 föregås inte av någon verbal sådan, utan tränaren lyfter bara sin pinne och motionären följer.

Efter att båda två har sänkt sina pinnar på rad 18 och 19 producerar tränaren den frasformade instruktionen å axlarna samtidigt som hon för sina axlar i en cirkel (r. 20, 21; se bild 5). Motionären svarar genom att omedelbart göra en liknande rörelse (r. 22). Nominalfrasen å axlarna fäster motionärens uppmärksamhet vid den kroppsdel som är central vid detta moment i övningen (jfr Rantala-Ekholm 1999 om substantiv under ishockeyträningar på finska; Sorjonen \& Raevaara 2014 om substantiv i servicesituationer på finska). Ljudstyrkan och tonhöjden i frasen är lägre än i tidigare instruktioner, och röstkvaliteten en 
Bild 5. Positionerna när å axlarna produceras. Motionären till vänster.

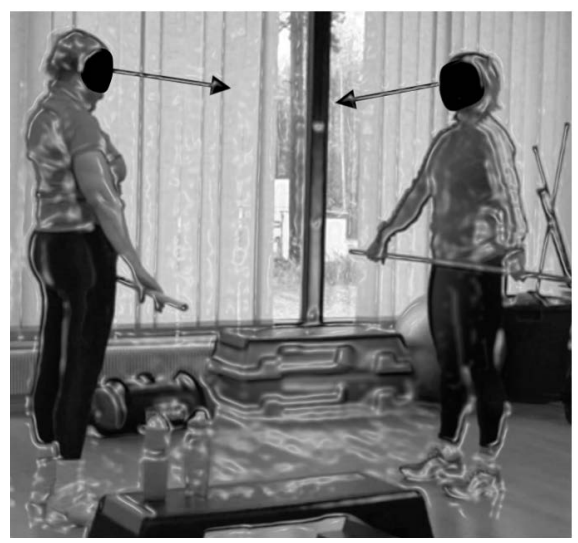

aning knarrig, vilket bidrar till att instruktionen framstår som den sista i en serie av flera instruktioner (jfr Huhtamäki 2012).

Därefter producerar tränaren uppföljningen bra (r. 23), vilket är en evaluering av lägre positiv grad. Den kan beskrivas som prosodiskt nertonad, eftersom den börjar på en lägre tonhöjd än föregående tur och är mycket tyst (jfr Curl 2002, Ogden 2006). Samtidigt fungerar dessa prosodiska drag, tillsammans med en knarrig röstkvalitet, slutsignalerande. Med evalueringen uttrycker tränaren att motionärens prestation är tillräcklig, och att denna repetition är slut.

Både det frasformade yttrandet å axlarna och den visuella demonstrationen är viktiga för att motionären ska kunna utföra detta moment. Till skillnad från de instruktioner Keevallik (2013) undersökt produceras den verbala och den fysiska delen av instruktionen nästan samtidigt. Deltagarnas placering mitt emot varandra är av stor betydelse för att motionären ska förstå instruktionen och tränaren producera den vid exakt rätt tidpunkt. Till motionärens förståelse av frasen bidrar också hennes kännedom om aktiviteten och deltagarnas roller. Likaså skapar raden av tidigare instruktioner, inledda med ett additivt $\stackrel{a}{a}$, förväntningar på att också detta yttrande ska fungera som en instruktion. Det frasformade yttrandet bidrar därtill till rytmen i övningen, genom att ange exakt när rörelsen ska utföras.

Utdragen ovan illustrerar hur frasformade yttranden används och förstås som instruktioner av deltagarna i personlig träning. Den sekventiella analysen visar att koordineringen mellan verbala och fysiska handlingar är avgörande för tolkningen. Det är ofta centralt att motionären och tränaren ser varandra, eller att de har kontakt genom beröring. En annan viktig faktor är att tränarna väl- 
jer ut centrala element i situationen, nämligen en kroppsdel, en riktning eller det faktum att motionären ska utföra ett visst antal repetitioner. Ibland kombineras flera av dessa i samma instruktion. Därtill bidrar motionärernas förförståelse av situationen och deras förväntan på nästa steg i övningen till att yttrandena uppfattas som instruktioner. Deltagarnas institutionella roller kan heller inte överskattas, eftersom tränaren förväntas instruera och motionären följa instruktionerna. De frasformade instruktionerna fungerar även som verbalt material. Det vill säga de ger tränaren ljud att uttala som gör det möjligt att styra tempot och intensiteten i övningarna med rösten.

\subsection{Uppföljningar av den fysiska prestationen efter en frasformad instruktion}

I träningssessionerna bildar en frasformad instruktion, det fysiska utförandet av övningen och en eventuell uppföljning en IRU-sekvens. Som tidigare nämnts har vi använt motionärens fysiska responser för att se vilka av tränarens frasformade yttranden som tolkas som instruktioner. Tränarens uppföljningar efter den fysiska responsen visar i sin tur hur väl motionären förstått tränarens instruktion. Uppföljningar förekommer naturligtvis även efter instruktioner som inte är frasformade, men de faller utanför ramen för denna undersökning.

Efter vissa av de frasformade instruktionerna i materialet producerar tränaren uppföljningar efter motionärens fysiska prestation, men det förekommer även att dessa saknas. När uppföljningar saknas är det inte nödvändigtvis så att motionärens fysiska respons är inkorrekt. I stället visar tränaren genom att genast gå vidare i programmet att responsen var korrekt och tillräcklig.

De uppföljningar som till sin lexikala betydelse bekräftar att motionären utfört övningen korrekt har vi kallat bekräftande uppföljningar. Dessa utgörs exempelvis av så, yes eller dit ja (se ex. 5 r. 14). Andra uppföljande turer evaluerar motionärens prestation, och dessa evalueringar kan vara av lägre eller högre grad. Som evalueringar av lägre grad har vi definierat uppföljningar av typen bra (se ex. 6 r. 23), medan vi betraktar uppföljningar som uttrycker något utöver detta som evalueringar av högre grad, exempelvis ja: super (jfr Pomerantz 1984, Antaki m.fl. 2000, Lindström m.fl. 2019). Många av uppföljningarna är alltså frasformade. 
Uppföljningarna fungerar både som evalueringar av prestationen och som övergångssignaler före nästa moment $\mathrm{i}$ övningen eller nästa övning (jfr Norrby m.fl. 2018 och Lindström m.fl. 2019 för tredjedrag i servicesamtal). Speciellt används bekräftande uppföljningar och evalueringar av lägre positiv grad som övergångssignaler mellan övningar eller moment under träningssessionerna, men den lexikala utformningen anger inte nödvändigtvis om uppföljningen är mer en evaluering eller en övergångssignal. Funktionen av övergångssignal förstärks genom att tränarna ofta har blicken riktad bort från motionären och vänder sig mot platsen för nästa övning när de uttalar uppföljningen (jfr Goodwin \& Goodwin 1987, Rossano 2013). Somliga uppföljningar förekommer efter ett visst moment inne i en övning, medan andra förekommer efter ett övningsset. Ett påfallande drag är att många uppföljningar följs av en ny instruktion i samma tur. Vid ett tillfälle ger tränaren instruktionen två till och motionären utför rörelsen ytterligare två gånger, varefter tränaren säger yes vi tar vänster utan paus mellan uppföljning och instruktion. Många av de instruktioner som produceras direkt efter en uppföljning handlar om byte av sida eller att motionären får ta en liten paus: bra (.) vilar vi där.

Prosodiskt faller uppföljningarna i två grupper: en typ som uttalas mer framträdande än föregående frasformade instruktion, till exempel genom högre tonhöjd och långsammare talhastighet, och en typ som uttalas mycket snabbt och liksom i förbigående, vilket tonar ner uppföljningens aspekt av beröm. När tränarna producerar evalueringar av högre positiv grad använder de ofta klart större ljudstyrka och tonomfång och/eller högre tonhöjd samt förlänger något ljud, dvs. uppgraderad prosodi (jfr Curl 2002, Ogden 2006), men uppgraderad prosodi och lexikalt högre grad sammanfaller inte nödvändigtvis.

\subsection{En jämförelse mellan Finland och Sverige}

I detta avsnitt jämför vi inspelningarna från Finland och Sverige med varandra. När det gäller den institutionella kontexten finner vi inga uppenbara skillnader mellan länderna, vare sig när det gäller aktiviteter eller utformningen av den fysiska kontexten. I fråga om antalet och typen av frasformade instruktioner, liksom uppföljningar, finns det däremot vissa skillnader.

Av de 617 frasformade instruktionerna i vårt material förekommer 406 under de finlandssvenska träningspassen, medan drygt hälften så många, 211, förekommer under de sverigesvenska (se tabell 2). Att frasformade instruktioner är vanligare i Finland kunde peka på att finlandssvenska tränare är mer direkta 
i sin verbala utformning av instruktioner, vilket är en liknande tendens som Henricson \& Nelson (2017) fann i sin studie av råden i handledarsamtal. Eftersom vi inte räknat hur stor andel de frasformade instruktionerna utgör av alla instruktioner är det dock svårt att veta om skillnaden är utslag av individuella variationer eller kan kopplas till varieteterna. Typen av träning varierar något mellan de olika inspelningarna, t.ex. hur högt tempot är och hur mycket precision som krävs i rörelserna. Ju mer precisionskrävande rörelserna är, desto fler frasformade (och andra) instruktioner.

Tabell 2. Fördelningen av olika typer av referens till situerade element, antal och andel.

\begin{tabular}{|c|c|c|c|c|c|c|c|}
\hline & \multicolumn{2}{|c|}{ Räkning } & \multicolumn{2}{|c|}{ Kropp och/eller riktning } & \multicolumn{2}{|c|}{ Övriga } & \multirow[b]{2}{*}{ Totalt per land } \\
\hline & antal & andel & antal & andel & antal & andel & \\
\hline Finland & $134^{6}$ & $33 \%$ & 205 & $50 \%$ & 71 & $17 \%$ & 407 \\
\hline Sverige & 123 & $58 \%$ & 61 & $29 \%$ & 26 & $12 \%$ & 210 \\
\hline Totalt & 251 & $40 \%$ & 264 & $43 \%$ & 102 & $17 \%$ & 617 \\
\hline
\end{tabular}

Fördelningen mellan olika typer av referenser till situerade element skiljer sig något mellan Finland och Sverige. Medan omnämnande av kropp och/eller riktning är den vanligaste typen (50\%) i det finlandssvenska delmaterialet, är räkning den vanligaste typen i det sverigesvenska (58 \%). Skillnaderna beror troligen på att typen av övningar varierar mellan inspelningarna, exempelvis sådana övningar som kräver noggranna instruktioner och sådana som kräver mer generella.

Det finns mer markanta skillnader mellan Finland och Sverige när det gäller hur ofta och med vilken typ av yttrande tränarna följer upp motionärernas prestationer efter en instruktion. Uppföljningar är överlag mer frekventa i det sverigesvenska delmaterialet: 44 procent av prestationerna följs upp i Sverige, medan endast 25 procent följs upp i Finland (se tabell 3). Vidare utgörs största delen av uppföljningarna i Finland av bekräftande sådana, exempelvis $s a ̊$, medan evalueringar av lägre positiv grad, såsom bra, utgör den största gruppen i Sverige. Evalueringar av högre positiv grad, exempelvis snyggt gött, är därtill klart vanligare i Sverige än i Finland. Mönstret påminner om det som Lindström med flera (2019) fann i sin undersökning av värderingar i servicesamtal i Finland och Sverige, nämligen att värderingar tenderar vara mer uppgraderade i Sverige (jfr även Henricson \& Nelson 2017 om handledningssamtal). I

\footnotetext{
${ }^{6}$ Det finns tre fall i det finlandssvenska materialet där kropp och/eller riktning kombineras med räkning, vilket innebär att summan av de olika typerna överstiger det totala antalet frasformade instruktioner.
} 
båda delmaterialen är bra den vanligaste uppföljningen: 34 stycken i Sverige och 18 stycken i Finland.

Tabell 3. Uppföljning av den fysiska prestationen efter en frasformad instruktion. $^{7}$

\begin{tabular}{lcccr}
\hline & \multicolumn{2}{c}{ Finland $^{8}$} & \multicolumn{2}{c}{ Sverige $^{9}$} \\
& Antal & Andel & Antal & Andel \\
\hline Bekräftande uppföljningar & 55 & $54 \%$ & 18 & $19 \%$ \\
Evalueringar av lägre positiv grad & 36 & $35 \%$ & 47 & $51 \%$ \\
Evalueringar av högre positiv grad & 11 & $11 \%$ & 28 & $30 \%$ \\
Totalt & 102 & $100 \%$ & 93 & $100 \%$ \\
\hline
\end{tabular}

Det finns alltså vissa skillnader mellan de två delmaterialen. Det förekommer fler frasformade instruktioner i det finlandssvenska delmaterialet än i det sverigesvenska, och vilken typ av instruktioner som är vanligast skiljer sig också. Det förekommer däremot fler uppföljningar efter en fysisk prestation i det sverigesvenska delmaterialet, och uppföljningarna är oftare uppgraderade än i det finlandssvenska delmaterialet.

\section{Sammanfattning och avslutande diskussion}

I denna artikel har vi presenterat en undersökning av en typ av interaktion som är så gott som obeforskad inom det språkvetenskapliga fältet, nämligen personlig träning. I undersökningen fokuserar vi på korta yttranden som vi valt att kalla frasformade instruktioner, vilka tidigare inte belysts på svenska i denna typ av kontext. Som frasformade instruktioner har vi definierat yttranden som 1) saknar finit verb, 2) utgör självständiga syntaktiska, prosodiska och pragmatiska enheter och 3) uppmanar till en fysisk handling som följande drag. Vi har undersökt hur frasformade yttranden fungerar som instruktioner i personlig träning samt jämfört hur dessa yttranden används i ett finlandssvenskt och ett sverigesvenskt delmaterial.

Vår undersökning visar att betydelsen hos frasformade instruktioner i per-

\footnotetext{
${ }^{7}$ Vi har räknat en uppföljande tur som en uppföljning och klassificerat den enligt det element som har högst grad i turen, exempelvis där ja bra räknas som en evaluering av lägre positiv grad även om den också innehåller den bekräftande uppföljningen där ja.

${ }^{8}$ Två osäkra uppföljningar i det finlandssvenska materialet har ej räknats med: en otydlig och en svårklassificerad.

${ }^{9}$ I det sverigesvenska materialet ingår tre uppföljningar producerade av andra motionärer under gruppträningen.
} 
sonlig träning endast i en viss utsträckning bygger på deras verbala utformning. Därtill utnyttjar deltagarna alla tillgängliga semiotiska resurser för att förstå dem, nämligen den övergripande aktiviteten, de institutionella rollerna som tränare och motionär, kropparnas position och rörelser i rummet, tidigare interaktion samt icke-verbala drag hos instruktionerna (jfr Goodwin 2000).

Eftersom den övergripande aktiviteten utgörs av personlig träning har både tränare och motionärer förväntningar om att det deltagarna säger i första hand ska handla om de fysiska övningarna. Ofta produceras de frasformade instruktionerna när övningen redan introducerats, så att de är inbäddade i ett pågående projekt (jfr Lindström m.fl. 2017 om imperativer). De utgör ofta preciseringar eller korrigeringar av övningarna. De frasformade instruktionerna kan jämföras med kontrollinstruktioner som syftar till en omedelbar handling enligt De Stefanis \& Gazins (2014) indelning.

Vidare är de frasformade instruktionerna möjliga på grund av den självklara auktoritet som den personliga tränaren har under träningen (jfr Stevanovic \& Peräkylä 2012). Det finns en tydlig rollfördelning mellan vem som har rättighet att ge instruktioner och vem som drar nytta av att följa dem: tränaren förväntas ge instruktioner och motionären följa dem (jfr Curl \& Drew 2008, CouperKuhlen 2014, Lundin 2018). Att de frasformade yttrandena uppfattas som instruktioner beror alltså i hög grad på deltagarnas uppfattningar om sina egna och varandras förpliktelser i situationen.

Element i den fysiska miljön, såsom olika träningsredskap, styr kroppsrörelserna hos deltagarna (jfr Cekaite 2010). I vissa fall får det verbala innehållet stöd av kroppsliga element i instruktionen, det vill säga tränaren kombinerar den frasformade instruktionen med en visuell-kroppslig eller taktil-kroppslig demonstration. Ett frasformat yttrande kan emellertid fungera som instruktion också utan kroppsliga element, vilket är en skillnad mot de syntaktiskt-kroppsliga konstruktioner som Keevallik (2013) beskriver.

Resultatet påminner om ett antal undersökningar av frasformade yttranden och imperativer inom andra typer aktiviteter, såsom körlektioner på italienska respektive tyska (se De Stefani \& Gazin 2014, Deppermann 2018), aerobictimmar och ishockeyträningar på finska (se Torpo 1998, Rantala-Ekholm 1999) och servicesituationer på finska (se Sorjonen \& Raevaara 2014). Militära kommandon är ett område som Svenska Akademiens grammatik (1999, 4 s. 814) nämner. Gemensamma drag i dessa institutionella kontexter är att rollfördelningen är tydlig, att deltagarnas förståelse av verksamheten är stor, att den fysiska miljön begränsar handlingarna och att det är frågan om uppmaningar som skapar förväntningar på en fysisk respons. 
Vi fann inte någon speciell »uppmaningsprosodi» som skulle förtydliga de frasformade yttrandenas funktion som instruktioner (jfr SAG 1999, 4 s. 677, Gårding 1998 s. 121-122, Huhtamäki 2014). Stigande slutintonation förekommer visserligen hos vissa instruktioner, men även hos de uppföljande yttrandena. Den stigande intonation som används i de instruerande sekvenserna används sannolikt för att signalera att yttrandena utgör punkter på en lista och pekar således framåt i interaktionen (jfr Karlsson 2010, Huhtamäki 2015).

Frasformade instruktioner handlar alltså i många fall om detaljer i övningen, och de är bara i vissa fall nödvändiga för att övningen ska framskrida. I flera av de analyserade exemplen skulle motionären troligen ha utfört övningen på rätt sätt även utan tränarens instruktion. Det innebär att den instruerande dimensionen inte alltid är i förgrunden, utan det frasformade yttrandet används även för att uppmuntra motionären genom pågående interaktion. Detta gäller speciellt instruktionerna som inkluderar räkning, som ofta uttalas före den sista repetitionen av en viss rörelse.

Utifrån vår undersökning kan vi konstatera att frasformade yttranden inte bara är möjliga att förstå som instruktioner i personlig träning, utan de är också mycket väl anpassade till denna kontext. Tack vare att de är korta och komprimerade går det snabbt att uttala dem (jfr De Stefani \& Gazin 2014). På så sätt är de lätta att koordinera med den fysiska aktiviteten. En frasformad instruktion kan skjutas in strax före ett moment, och användas för att finjustera motionärens pågående prestation (jfr Deppermann 2018). Genom att instruktionerna är så korta är det också lätt för motionären att veta vilka aspekter tränaren fokuserar. De frasformade instruktionerna innehåller en begränsad mängd grammatisk information men refererar till situerade element i träningen vilket underlättar för motionären att förstå dem. De frasformade instruktionerna har också funktionen av verbalt material som tränaren kan uttala för att ange tempo och intensitet hos övningarna.

Frasformade instruktioner används nästan dubbelt så ofta i det finlandssvenska som i det sverigesvenska delmaterialet. Eftersom frasformade instruktioner kan sägas vara direkta och icke-modulerade kan detta resultat visa på en liknande tendens som hos råd i handledningssamtal i dessa länder (se Henricson \& Nelson 2017). I det sverigesvenska delmaterialet följs en större andel av de fysiska prestationerna upp. Därtill används evalueringar av lägre och högre positiv grad oftare i Sverige, medan allmänt bekräftande uppföljningar är vanligast i Finland. Resultatet pekar alltså i samma riktning som tidigare studier av skillnader mellan finlandssvensk och sverigesvensk interaktion, nämligen att uppbackningar och värderingar tenderar vara mer uppgraderade i Sverige (se 
Henricson \& Nelson 2017, Lindström m.fl. 2019). Dessa skillnader hör troligen samman med skillnader i de respektive kulturer där finlandssvenska och sverigesvenska talas.

\section{Transkriptionsnyckel}

(jfr Lindström 2008 s. 309, Hepburn \& Bolden 2013)

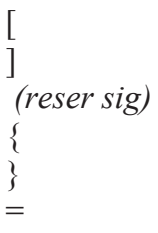

(.)

$\mathrm{mm}+\mathrm{m}$

sista:

foten

BRA

${ }^{\circ} \mathrm{bra}^{\circ}$

$>$ upp $<$

$<$ upp $>$

*ja tänkt*

.h

h.

.HH

$\mathrm{HH}$.

(ett)

(ohb)

?

hälen överlapp inleds

överlapp slutar

kommentar om en deltagares fysiska handling

samtidig fysisk handling inleds

samtidig fysisk handling avslutas

1) yttranden hakas på varandra utan paus

2) yttrandet fortsätter på annan rad

mikropaus (under 0,2 sekunder)

paus uttryck i sekunder

ljudet uttalas med brott inuti

förlängt ljud

starkt betonad stavelse

tal med högre ljudstyrka än omgivande tal

tal med lägre ljudstyrka än omgivande tal

tal som är snabbare än omgivande tal

tal som är långsammare än omgivande tal

tal med skratt i rösten

hörbar inandning

hörbar utandning

lång och ljudlig inandning

lång och ljudlig utandning

transkriptionen är osäker

ohörbart

fallande slutintonation

jämn slutintonation

stigande slutintonation

fetstil används för de frasformade instruktionerna

\section{Litteratur}

Antaki, Charles, Houtkoop Steenstra, Hanneke \& Rapley, Mark, 2000: "Brilliant. Next question." High-grade assessment sequences in the completion of interactional units. I: Research on language and social interaction 33. S. 235-262.

Blommaert, Jan \& Jie, Dong, 2010: Ethnographic fieldwork: a beginner's guide. Bristol: Multilingual matters. 
Bockgård, Gustav, 2007: Syntax och prosodi vid turbytesplatser. Till beskrivningen av svenskans turtagning. I: E. Engdahl \& A.-M. Londen (red.): Interaktion och kontext. Nio studier av svenska samtal. Lund: Studentlitteratur. S. 139-183.

Cekaite, Asta, 2010: Shepherding the child: embodied directive sequences in parentchild interactions. I: Text \& talk 30:1. S. 1-25.

Couper-Kuhlen, Elizabeth, 2014: What does grammar tell us about action? I: Pragmatics 24:3. S. 623-647.

Couper-Kuhlen, Elizabeth \& Selting, Margret, 2001: Introducing interactional linguistics. I: M. Selting \& E. Couper-Kuhlen (red.): Studies in interactional linguistics. Amsterdam/Philadelphia: John Benjamins publishing company. S. 1-22.

Couper-Kuhlen, Elizabeth \& Selting, Margret, 2018: Interactional linguistics: Studying language in social interaction. Cambridge: Cambridge University Press.

Curl, Traci S., 2002: The phonetics of sequence organization: an investigation of lexical repetition in other-initiated repair sequences in American English. Doctoral dissertation. Department of linguistics, University of Colorado.

Curl, Traci S. \& Drew, Paul, 2008: Contingency and action: a comparison of two forms of requesting. I: Research on language and social action 41:2. S.129-153.

De Stefani, Elwys \& Gazin, Anne-Danièle, 2014: Instructional sequences in driving lessons: Mobile participants and the temporal and sequential organization of actions. I: Journal of pragmatics 65. S. 63-79.

Deppermann, Arnulf, 2018: Instructing practices in German driving lessons: Differential uses of declaratives and imperatives. I: International journal of applied linguistics 28:2. S. 265-282.

Drew, Paul \& Heritage, John, 1992: Analyzing talk at work: an introduction. I: P. Drew \& J. Heritage (red.): Talk at work: interaction in institutional settings. Cambridge: Cambridge University press. S. 3-65.

Ford, Cecilia \& Thompson, Sandra, 1996: Interactional units in conversation: syntactic, intonational, and pragmatic resources for the management of turns. I: E. Ochs, E. Schegloff \& S. Thompson (red.): Interaction and grammar. (Studies in interactional sociolinguistics 13.) Cambridge: Cambridge University press. S. 134-184.

George, Molly, 2008: Interactions in expert service work. Demonstrating professionalism in personal training. I: Journal of contemporary ethnography 31:1. S. 108-131. https://doi.org/10.1177/0891241607309498.

Goffman, Ervin, 1981: Forms of talk. Oxford: Basil Blackwell.

Goodwin, Charles, 2000: Action and embodiment within situated human interaction. I: Journal of pragmatics 32. S. 1489-1522.

Goodwin, Charles \& Goodwin, Marjorie H., 1987: Concurrent operations on talk: notes on the interactive organization of assessments. I: IPrA Papers in Pragmatics 1:1. S. 1-55.

Grahn, Inga-Lill, 2017: Initierande tackhandlingar i sverigesvenska och finlandssvenska vårdsamtal - sekvensorganisering och funktion. I: Språk och interaktion 4: 4. S. 89-110. http://hdl.handle.net/10138/229739.

Grahn, Inga-Lill \& Huhtamäki, Martina, 2019: Frasformade instruktioner under fysisk aktivitet - form och funktion i interaktionell belysning. I: M. Bianchi, D. Håkansson, B. Melander, L. Pfister, M. Westman \& C. Östman (red.): Svenskans beskrivning 36. Förhandlingar vid trettiosjätte sammankomsten. Uppsala 25-27 oktober 2017. Uppsala: Institutionen för nordiska språk vid Uppsala universitet. S. 65-78. 
Henricson, Sofie \& Nelson, Marie, 2017: Giving and receiving advice in higher education. Comparing Sweden-Swedish and Finland-Swedish supervision meetings. I: Journal of pragmatics 109. S. 105-120. http://www.sciencedirect.com/science/journal $/ 03782166$.

Hepburn, Alexa \& Bolden, Galina B., 2013: The conversation analytic approach to transcription. I: J. Sidnell \& T. Stivers (red.): The handbook of conversation analysis. Chichester: Wiley-Blackwell. S. 57-76.

Heritage, John, 1997: Conversational analysis and institutional talk: analyzing data. I: D. Silverman (red.): Qualitative research: theory, method and practice. London: Sage Publications. S. 161-182.

Heritage, John \& Sorjonen, Marja-Leena, 1994: Constituting and maintaining activities across sequences: And-prefacing as a feature of question design. I: Language in society 23. S. 1-29.

Huhtamäki, Martina, 2012: Prosodiska drag i frågor. En undersökning av Helsingforssvenska samtal. I: Språk och stil NF 22:2. S. 153-184.

Huhtamäki, Martina, 2014: Intonation och funktion hos frågor med icke-interrogativ syntax. En undersökning av Helsingforssvenska flerpersonssamtal. Tal och språk 34:4. S. 147-173.

Huhtamäki, Martina, 2015: Frågor med stigande och jämn slutintonation i Helsingforssvenska samtal. I: Folkmålsstudier 53: Meddelanden från Föreningen för nordisk filologi. S. 79-115.

af Hällström-Reijonen, Charlotta \& Reuter, Mikael, 2008: Finlandssvensk ordbok. Forskningscentralen för de inhemska språken. Helsingfors: Schildts förlags Ab. Tillgänglig på http://kaino.kotus.fi/fsob/?p=main.

Jefferson, Gail, 1990: List construction as a task and interactional resource. I: G. Psathas (red.): Interaction Competence. Washington D.C.: University Press of America. S. 63-92.

Karlsson, Susanna, 2010: Multimodalitet i listproduktion. I: Språk och interaktion 2. S. 141-170. http://hdl.handle.net/10138/28555.

Keevallik, Leelo, 2013: The interdependence of bodily demonstrations and clausal syntax. I: Research on language and social interaction 46:1. S. 1-21. https://doi.org/ 10.1080/08351813.2013.753710.

Lindström, Jan, 2008: Tur och ordning. Introduktion till svensk samtalsgrammatik. Stockholm: Norstedts akademiska förlag.

Lindström, Jan, Lindholm, Camilla, Grahn, Inga-Lill \& Huhtamäki, Martina, u.u.: Consecutive clause combinations in instructing activities: Directives and accounts in the context of physical training. I: Y. Maschler, S. Pekarek Doehler, J. Lindström \& L. Keevallik (red.): Emergent syntax for conversation: Clausal patterns and the organization of action. Amsterdam: John Benjamins publishing company.

Lindström, Jan, Lindholm, Camilla, Norrby, Catrin, Wide, Camilla \& Nilsson, Jenny, 2017: Imperatives in Swedish medical consultations. I: M.-L. Sorjonen, L. Raevaara \& E. Couper-Kuhlen (red.): Imperative turns at talk: The design of directives in action. Amsterdam: John Benjamins publishing company. S. 299-324.

Lindström, Jan, Norrby, Catrin, Wide, Camilla \& Nilsson, Jenny, 2019: Task-completing assessments in service encounters. I: Research on language and social interaction 52:2. S. 85-103. doi: 10.1080/08351813. 2019. 1581468 
Lindwall, Oskar, Lymer, Gustav \& Greiffenhagen, Christian, 2015: The sequential analysis of instruction. I: N. Markee (red.): The handbook of classroom discourse and interaction. Maiden, MA: Wiley-Blackwell. S. 142-157.

Linell, Per, 2011: Samtalskulturer. Kommunikativa verksamhetstyper i samhället. (Studies in language and culture 18.) Linköping: Institutionen för kultur och kommunikation, Linköpings universitet.

Lundin, Katarina, 2018: Att instruera i idrottskontext. Educare 2018:1. S. 140-169.

Macbeth, Douglas, 2003: Hugh Mehan's "Learning Lessons" reconsidered: on the differences between the naturalistic and critical analysis of classroom discourse. I: American educational research journal 40:1. S. 239-280.

Martin, Cathrin, 2004: From other to self. Learning as interactional change. Doktorsavhandling. Uppsala: Pedagogiska institutionen, Uppsala universitet.

Martin, Cathrin \& Sahlström, Fritjof, 2010: Learning as longitudinal interactional change: From other-repair to self-repair in physiotherapy treatment. I: Discourse Processes 47:8. S. 668-697.

Mehan, Hugh, 1979: Learning lessons: Social organization in the classroom. Cambridge, MA: Harvard University press.

Mondada, Lorenza, 2011: Understanding as an embodied, situated and sequential achievement in interaction. I: Journal of pragmatics 43:2. S. 542-552.

Nilsson, Jenny, Norrthon, Stefan, Lindström, Jan \& Wide, Camilla, 2018: Greetings as social action in Finland Swedish and Sweden Swedish service encounters - a pluricentric perspective. I: Intercultural pragmatics 15:1. S. 57-88. doi:10.1515/ ip-2017-0030. https://helda.helsinki.fi/handle/10138/234613.

Nishizaka, Aug, 2016: Syntactical constructions and tactile orientations: procedural utterances and procedures in massage therapy. I: Journal of pragmatics 98. S. 18-35.

Norrby, Catrin, Lindström, Jan, Wide, Camilla \& Nilsson, Jenny, 2018: Kivasvenska och kanonsvenska. Sekvensavslutande värderingar i servicesamtal. I: B. Silén, A. Huhtala, H. Lehti-Eklund, J. Stenberg-Sirén, \& V. Syrjälä (red.): Svenskan i Finland 17. Helsingfors: Helsingfors universitet. S. 107-117.

Norrby, Catrin, Wide, Camilla, Lindström, Jan \& Nilsson, Jenny, 2012: Finland Swedish as a non-dominant variety of Swedish - extending the scope to pragmatic and interactional aspects. I: R. Muhr (red.): Non-dominant varieties of pluricentric languages: Getting the picture. In memory of Michael Clyne. Frankfurt am Main: Peter Lang. S. 49-62.

Norrby, Catrin, Wide, Camilla, Lindström, Jan \& Nilsson, Jenny, 2014: Finns det nationella svenska kommunikationsmönster? Tilltal i läkare-patientsamtal i Sverige och Finland. I: J. Lindström, S. Henricson, A. Huhtala, P. Kukkonen, H. Lehti-Eklund \& C. Lindholm (red.): Svenskans beskrivning 33. (Nordica Helsingiensia 37.) Helsingfors: Finska, finskugriska och nordiska institutionen, Helsingfors universitet. S. 343-352. http://hdl.handle.net/10138/144498.

Ogden, Richard, 2006: Phonetics and social action in agreements and disagreements. I: Journal of pragmatics 38:10. S. 1752-1775. https://doi.org/10.1016/j.pragma.2005.04.011.

Placencia, María Elena, 2008: Requests in corner shop transactions in Ecuadorian Andean and Coastal Spanish. I: K. P. Schneider \& A. Barron (red.): Variational pragmatics. A focus on regional varieties in pluricentric languages. Amsterdam: John Benjamins publishing company. S. 307-332. 
Pomerantz, Anita, 1984: Agreeing and disagreeing with assessments: Some features of preferred/dispreferred turn shapes. I: J. Heritage \& J. M. Atkinson (red.): Structures of social action: Studies in conversation analysis. Cambridge: Cambridge University Press. S. 57-101.

Rantala-Ekholm, Kati, 1999: Kiekko liikkuu, kiekko liikkuu: Jääkiekkovalmennuksen direktiiveistä [Om direktiv under ishockeyträningar]. Pro gradu-avhandling. Helsingfors: SKL, Helsingfors universitet.

Rossano, Federico, 2013: Gaze in conversation. I: J. Sidnell \& T. Stivers (red.): The handbook of conversation analysis. Chichester: Wiley-Blackwell. S. 308-329.

Sacks, Harvey \& Schegloff, Emanuel, 1973: Opening up closings. I: Semiotica VIII:4. S. 289-327.

Sacks, Harvey, Schegloff, Emanuel \& Jefferson, Gail, 1974: A simplest systematics for the organization of turn-taking for conversation. I: Language 50. S. 696-735.

SAG = Ulf Teleman, Staffan Hellberg \& Erik Andersson, 1999: Svenska Akademiens grammatik. Stockholm: Norstedts Ordbok.

Saville-Troike, Muriel, 2003: The ethnography of communication. An introduction. 3 upplagan. (Language in society 3.) Malden, MA: Blackwell publishing.

Schneider, Klaus P. \& Barron, Anne (red.), 2008: Variational pragmatics. A focus on regional varieties in pluricentric languages. Amsterdam: John Benjamins publishing company.

Sidnell, Jack, 2013: Basic conversation analytic methods. I: J. Sidnell \& T. Stivers (red.): The handbook of conversation analysis. Chichester: Wiley-Blackwell. S. 7799.

Sinclair, John \& Coulthard, Malcolm, 1975: Towards an analysis of discourse: The English used by teachers and pupils. London: Oxford University press.

Sorjonen, Marja-Leena \& Raevaara, Liisa, 2014: On the grammatical form of requests at the convenience store: Requesting as embodied action. I: P. Drew \& E. CouperKuhlen (red.): Requesting in social action. (Studies in language and social interaction 26.) Amsterdam: John Benjamins publishing company. S. 243-268.

Stevanovic, Melisa \& Peräkylä, Anssi, 2012: Deontic authority in interaction: the right to announce, propose, and decide. I: Research on language and social interaction 45: 3. S. 297-321. https://doi.org/10.1080/08351813.2012.699260.

Torpo, Lotta, 1998: Aerobic-tuntien direktiivit [Direktiv under aerobictimmar]. Pro gradu-avhandling. Helsingfors: SKL, Helsingfors universitet. 